\title{
Exploratory study of municipal wastewater primary sedimentation basin effluent treatment using an upflow anaerobic filter
}

Author: Mark McCormick, Environmental Engineer, M.Sc., Tel: +41 7860452 42,

mark_mccormick@hotmail.com

Revision date: 2021.10 .29

\begin{abstract}
This report describes the results of exploratory tests conducted using a 95-liter upflow anaerobic filter (UAF) bioreactor test unit fed raw primary sedimentation basin effluent at a municipal wastewater treatment plant. The main objectives of the exploratory study were to obtain substrate conversion and hydraulic data for use in making full-scale projections, evaluate potential biofilm support materials, and to assess the suitability of the upflow anaerobic filter unit process as part of a new concept for a complete municipal wastewater treatment plant. The tests were conducted using available equipment with no effort made to optimize the system. The main findings of the tests are: COD loading rate: 2,1 $\mathrm{kg} \mathrm{COD} / \mathrm{m}^{3} /$ day, hydraulic retention time: 3 hours, average influent energy conversion: $71 \%$ (Influent $\mathrm{HHV}$-effluent $\mathrm{HHV}$ ), biogas $\mathrm{CH}_{4}$ content up to $65 \%$, stable operation at $16^{\circ} \mathrm{C}$, evaluation of different biofilm support materials (see text), non-biodegradable ash and phenolic compounds account for at least $63 \%$ of the total solids contained in primary sedimentation basin effluent and they are the most important contributors to turbidity.
\end{abstract}

\section{Introduction}

This work was conducted as part of an effort to conceive a new wastewater treatment and resource recovery system to replace the conventional wastewater treatment plant designs. The aim is to achieve optimal conception of the system and integration of all unit processes to achieve minimal construction and operating cost, and maximal efficiency, profit, and environmental quality.

Some of the major problems inherent to conventional municipal wastewater treatment are:

- Production of excess activated sludge

- Recalcitrance to anaerobic digestion of activated sludge compared to primary sludge

- More than half of the available chemical potential energy is lost as $\mathrm{CO}_{2}$ released from the activated sludge and the anaerobic digestion processes

- Concentration of recalcitrant substances due to internal recycle

- All the produced electricity is consumed internally (none is profitably exported)

- Not all heat is used productively

- Requirement to add consumable chemicals to remove phosphorous and improve sludge sedimentation

In industrialized countries, the cost of wastewater treatment is affordable in terms of economic cost and energy consumption. Nevertheless, if conventional activated sludge processes were replaced by the proposed anaerobic UAF process, then wastewater treatment would be an energy producing activity and electricity could be exported from wastewater treatment plants and carbon emissions from fossil fuel consumption could be avoided. In the case of lower income countries, high operating costs, especially electricity purchases, might explain the current situation where more than 2,5 billion people are not served by wastewater treatment plants and billions more are poorly served by inadequate wastewater treatment. 
Conventional wastewater treatment relies on aeration and on aerobic microorganisms to oxidize the organic fraction of municipal wastewater to $\mathrm{CO}_{2}$ and to produce sludge that can be removed from water by decantation. This strategy and the first activated sludge processes were first implemented over 100 years ago. Nitrogen and phosphorous are removed by additional aerobic processes or by chemical precipitation. Although effective, conventional wastewater treatment requires approximately $7.5 \mathrm{~W} /$ capita of electrical power input, mostly for aeration. The total electricity requirement for wastewater treatment in Switzerland is approximately $500 \mathrm{GWh}$ per year. Up to $80 \%$ of this requirement can be met by on-site Combined Heat and Power (CHP) production using biogas fuel. Nevertheless, conventional wastewater treatment is very energy inefficient. In a typical wastewater treatment plant over $50 \%$ of the calorific value of the incoming wastewater solids is lost as $\mathrm{CO}_{2}$ produced by bacterial respiration. Moreover, the excess thermal energy produced by $\mathrm{CHP}$ is often not used and no electricity is exported to the grid. Energy flows from a typical activated sludge based wastewater treatment plant are described in the diagram below.

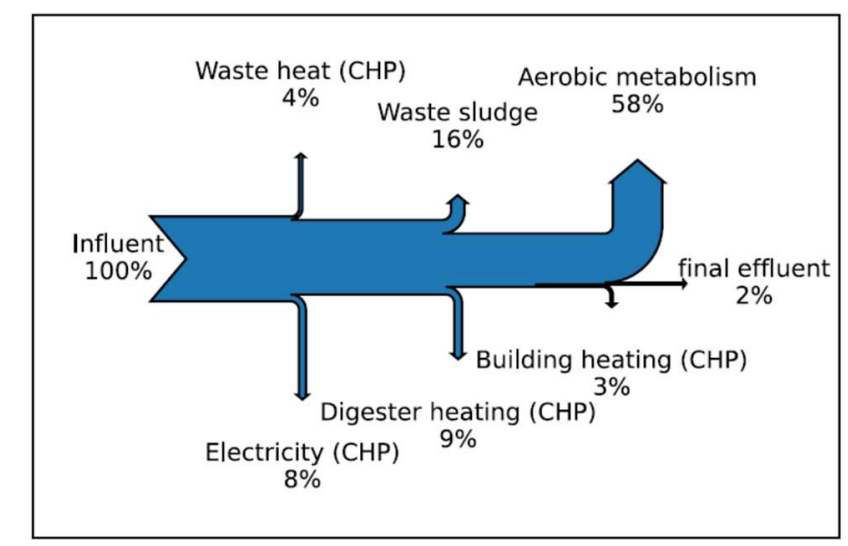

Figure 1 Energy balance of a conventional Activated Sludge WWTP

The upflow anaerobic filter (UAF) is an anaerobic digester that contains a packed bed of solid supports on which a biofilm develops. Influent enters below the filter and exits above the filter.

This study was conceived to explore the use of an UAF for the treatment of municipal wastewater primary effluent in real industrial conditions. The test equipment was recovered from previous projects and adapted to build the anaerobic filter with a very small budget for materials. This approach made it possible to acquire preliminary results that can be used to assess the feasibility and to orient the work on the preparation of new project proposals to make detailed designs of anaerobic filters and to develop new complete wastewater treatment plant system concepts.

The main research topics and questions addressed by this study were:

- What are the chemical conversion rates (biogas and VFA production, COD changes, etc)?

- What is the maximum loading rate?

- What is the minimum hydraulic retention time?

- Biofilm characteristics

- What materials should be used for biofilm supports?

- Material and energy balance

- Temperature effects

- Residence time distribution

- Effects on downstream denitrification

- Scale-up potential 
The quality of the results obtained during this exploratory study is not adequate for submission to a scientific journal. Nevertheless, they are reported here because they might contribute to efforts to improve urban wastewater treatment systems and technology.

\section{Material and methods}

A simple test unit was constructed to collect data continuously for a long duration under a wide variety of industrial operating conditions. Unfiltered, unheated UAF influent was taken directly from the wwtp primary sedimentation basin effluent and fed continuously to the test unit. The flow rate was regulated by a peristaltic pump. Temperature, biogas flow rate, $\mathrm{CH}_{4}, \mathrm{pH}$ and $\mathrm{ORP}$ were measured at appropriate intervals to permit continuous recording of operational data. A post digester decanter served as a gas/liquid/solid separator.
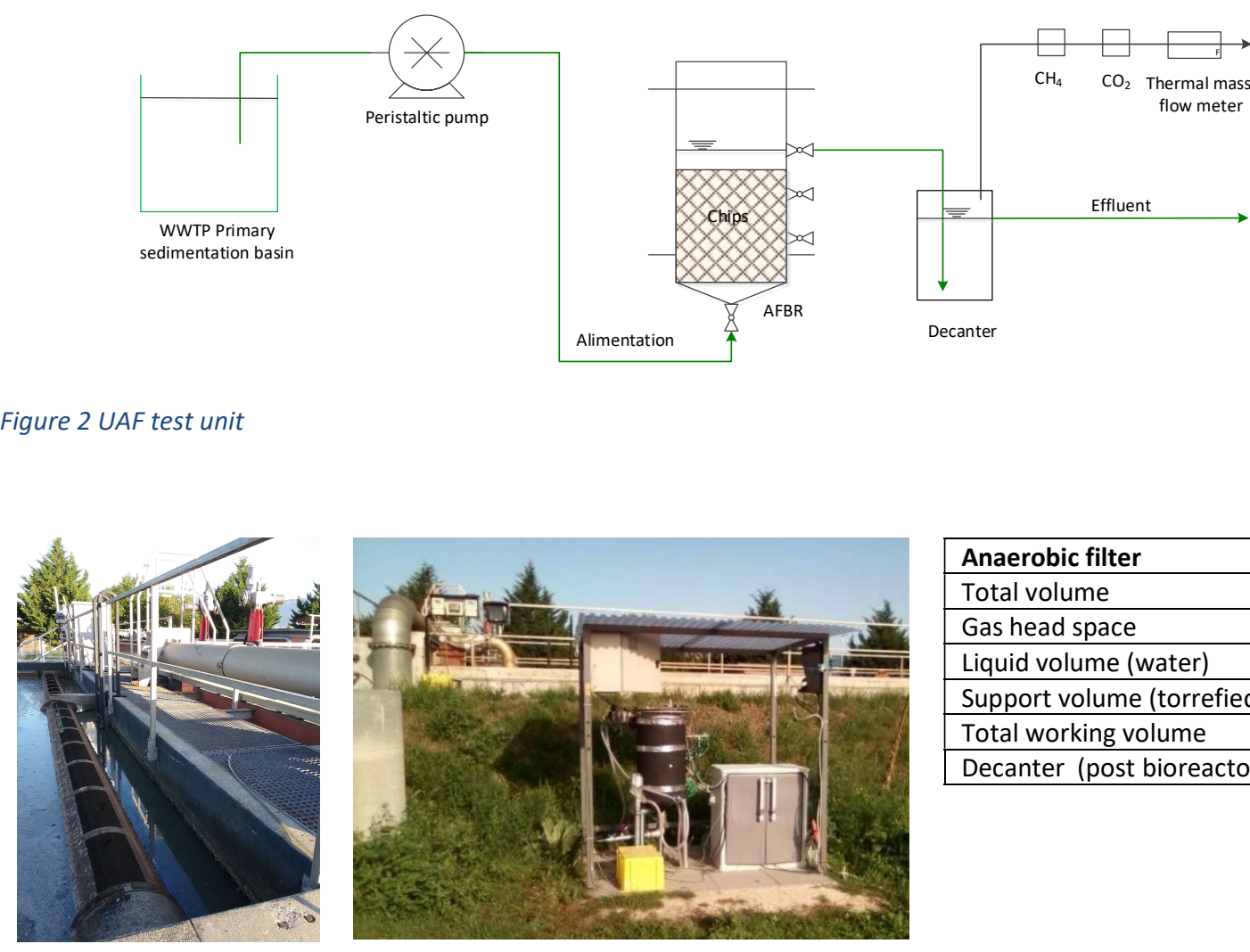

\begin{tabular}{|l|l|}
\hline Anaerobic filter & litres \\
\hline Total volume & 79 \\
\hline Gas head space & 23 \\
\hline Liquid volume (water) & 37 \\
\hline Support volume (torrefied & 19 \\
\hline Total working volume & 56 \\
\hline Decanter (post bioreactor) & 16 \\
\hline
\end{tabular}

Figure 3 UAF test unit (from left to right: inlet, test unit, compartment volumes)

From May 4 to December $15^{\text {th }} 2017$ ( 215 days) this test unit was operated almost continuously to treat primary sedimentation basin effluent from the municipal wastewater treatment plant in Yverdon-lesBains, Switzerland.

After conducting tests for more than 7 months at the wastewater treatment plant, the test unit was moved to the laboratory for residence time distribution studies using tap water with salt added to increase conductivity (described below in the results section).

\section{Anaerobic Filter Bed description}


The filter bed material was produced by heating wood chips at $250^{\circ} \mathrm{C}$ in an anoxic atmosphere (torrefaction). The average dimensions of the torrefied chips were $28 \times 8 \times 4 \mathrm{~mm}$. 30 liters of biofilm coated torrefied chips from a previous experiment were mixed with 12 liters of clean torrefied chips and loaded into the bioreactor. In order to investigate the use of other biofilm supports, different plastic test materials were placed in perforated containers that were buried in the torrefied chip anaerobic filter bed. The torrefied wood chips and the plastic samples were removed periodically, and the activity of the associated biofilm was evaluated.

\section{Results}

The measured parameters are shown in the table below and in figures in the text. Additionally, selected results are presented and commented below.

\section{Summary of major process parameters}

Samples were collected, and off-line measurements of the usual anaerobic digestion process parameters were made at 1 to 3-day intervals. Some parameters were measured weekly or even less frequently. Additional results are presented graphically at the end of this report and more are available on request.

Table 1 Summary of influent off-line measurements

\begin{tabular}{|c|c|c|c|c|c|}
\hline Parameter & Unit & Number & Mean & standard deviation & RSD \\
\hline Inlet flow rate & l/jour & 212 & 268 & 114 & 0.42 \\
\hline Inlet water temperature & ${ }^{\circ} \mathrm{C}$ & 118 & 19.10 & 7.51 & 0.39 \\
\hline $\mathrm{pH}$ & & 109 & 7.45 & 0.22 & 0.03 \\
\hline Total solids & $\%$ & 24 & 0.06 & 0.02 & 0.24 \\
\hline Total volatile solids & $\%$ of TS & 23 & 37.31 & 8.36 & 0.22 \\
\hline Ash & $\%$ of TS & 23 & 62.80 & 8.51 & 0.14 \\
\hline $\mathrm{HHV}$ & MJ/kg dry & 10 & 5.96 & 0.87 & 0.15 \\
\hline LHV & $\mathrm{MJ} / \mathrm{kg}$ dry & 9 & 5.48 & 0.88 & 0.16 \\
\hline $\mathrm{C}$ & $\%$ TS & 10 & 19.08 & 1.30 & 0.07 \\
\hline $\mathrm{H}$ & $\%$ TS & 10 & 2.37 & 0.24 & 0.10 \\
\hline $\mathrm{N}$ & $\%$ TS & 10 & 1.58 & 0.19 & 0.12 \\
\hline$S$ & $\%$ TS & 1 & 0.49 & & \\
\hline $\mathrm{O}$ & $\%$ TS & 10 & 14.2 & 1.41 & 0.02 \\
\hline tATP (total Adenosine triphosphate) & $\mathrm{ng} / \mathrm{l}$ & 5 & 68.54 & 45.97 & 0.67 \\
\hline VFA, expressed as acetate & $\mathrm{mg} / \mathrm{l}$ & 26 & 94.71 & 29.28 & 0.31 \\
\hline COD, dissolved & $\mathrm{mg} / \mathrm{l}$ & 13 & 255.74 & 90.92 & 0.36 \\
\hline COD, suspended & $\mathrm{mg} / \mathrm{l}$ & 13 & 429.46 & 144.95 & 0.34 \\
\hline COD, suspended (filtered $0,45 \mu \mathrm{m}$ ) & $\mathrm{mg} / \mathrm{l}$ & 4 & 264.50 & 38.53 & 0.15 \\
\hline COD, dissolved (filtered 0,45 $\mu \mathrm{m}$ ) & $\mathrm{mg} / \mathrm{l}$ & 4 & 276.50 & 36.59 & 0.13 \\
\hline TOC, dissolved & $\mathrm{mg} / \mathrm{l}$ & 10 & 80.70 & 29.69 & 0.37 \\
\hline TOC, suspended & $\mathrm{mg} / \mathrm{l}$ & 8 & 123.88 & 16.30 & 0.13 \\
\hline TOC, suspended (filtered $0,45 \mu \mathrm{m}$ ) & $\mathrm{mg} / \mathrm{l}$ & 2 & 59.90 & 19.66 & 0.33 \\
\hline TKN (LatoN) dissolved & $\mathrm{mg} / \mathrm{l}$ & 12 & 67.84 & 25.82 & 0.38 \\
\hline TKN (LatoN) suspended & $\mathrm{mg} / \mathrm{l}$ & 4 & 62.63 & 23.09 & 0.37 \\
\hline $\mathrm{NH} 4-\mathrm{N}$ & $\mathrm{mg} / \mathrm{l}$ & 26 & 53.12 & 21.38 & 0.40 \\
\hline NO3-N & $\mathrm{mg} / \mathrm{l}$ & 9 & 0.63 & 0.21 & 0.34 \\
\hline $\mathrm{PO} 4$ & $\mathrm{mg} / \mathrm{l}$ & 16 & 5.79 & 3.43 & 0.59 \\
\hline SO4 dissolved & $\mathrm{mg} / \mathrm{l}$ & 3 & 68.60 & 7.10 & 0.10 \\
\hline SO4 suspended & $\mathrm{mg} / \mathrm{l}$ & 1 & 93.40 & & \\
\hline Absorbence, $230 \mathrm{~nm}$ & A.U. & 12 & 0.01 & 0.02 & 2.10 \\
\hline Absorbence, centrifuged, $230 \mathrm{~nm}$ & A.U. & 9 & 0.01 & 0.02 & 2.24 \\
\hline Absorbence, $260 \mathrm{~nm}$ & A.U. & 28 & 0.88 & 0.60 & 0.68 \\
\hline Absorbence, centrifuged, $260 \mathrm{~nm}$ & A.U. & 9 & 0.26 & 0.06 & 0.24 \\
\hline Absorbence, $280 \mathrm{~nm}$ & A.U. & 12 & 0.63 & 0.31 & 0.49 \\
\hline Absorbence, centrifuged, $280 \mathrm{~nm}$ & A.U. & 9 & 0.34 & 0.08 & 0.23 \\
\hline Absorbence, $830 \mathrm{~nm}$ & A.U. & 28 & 0.25 & 0.16 & 0.64 \\
\hline
\end{tabular}




\begin{tabular}{|l|l|c|c|c|c|}
\hline Absorbence, centrifuged, $830 \mathrm{~nm}$ & A.U. & 9 & 0.10 & 0.04 & 0.44 \\
\hline Absorbence, $860 \mathrm{~nm}$ & A.U. & 28 & 0.24 & 0.16 & 0.65 \\
\hline Absorbence, centrifuged, $860 \mathrm{~nm}$ & A.U. & 9 & 0.08 & 0.03 & 0.42 \\
\hline Absorbence, $890 \mathrm{~nm}$ & A.U. & 27 & 0.23 & 0.15 & 0.67 \\
\hline Absorbence, centrifuged, $890 \mathrm{~nm}$ & A.U. & 9 & 0.07 & 0.03 & 0.43 \\
\hline HRT & hours & 209 & 4.66 & 5.69 & 1.22 \\
\hline
\end{tabular}

Table 2 Summary of effluent off-line measurements

\begin{tabular}{|c|c|c|c|c|c|}
\hline Parameter & Unit & Number & Mean & standard deviation & RSD \\
\hline pH (digester effluent) & & 29 & 7.14 & 0.16 & 0.02 \\
\hline $\mathrm{pH}$ (post digester decanter effluentl) & & 104 & 7.16 & 0.18 & 0.02 \\
\hline Temperature (decanter effluentl) & ${ }^{\circ} \mathrm{C}$ & 110 & 22.75 & 6.83 & 0.30 \\
\hline Total solids & $g / l$ & 24 & 0.05 & 0.01 & 0.20 \\
\hline Total volatile solids & $\%$ TS & 23 & 29.05 & 6.71 & 0.23 \\
\hline Ash & $\%$ TS & 23 & 70.95 & 6.71 & 0.09 \\
\hline $\mathrm{HHV}$ & MJ/kg dry & 10 & 2.31 & 1.06 & 0.46 \\
\hline LHV & $\mathrm{MJ} / \mathrm{kg}$ dry & 9 & 2.10 & 1.04 & 0.50 \\
\hline C & $\%$ TS & 10 & 13.49 & 1.73 & 0.13 \\
\hline $\mathrm{H}$ & $\%$ TS & 10 & 1.13 & 0.45 & 0.40 \\
\hline $\mathrm{N}$ & $\%$ TS & 10 & 0.97 & 0.27 & 0.28 \\
\hline $\mathrm{O}$ & $\%$ TS & 10 & 14.0 & 2.40 & 0.03 \\
\hline tATP (total Adenosine triphosphate & $\mathrm{ng} / \mathrm{l}$ & 4 & 70.97 & 42.19 & 0.59 \\
\hline VFA, expressed as acetate & $\mathrm{mg} / \mathrm{l}$ & 25 & 55.37 & 24.68 & 0.45 \\
\hline COD, dissolved & $\mathrm{mg} / \mathrm{l}$ & 16 & 124.23 & 50.66 & 0.41 \\
\hline COD, suspended & $\mathrm{mg} / \mathrm{l}$ & 10 & 221.82 & 58.69 & 0.26 \\
\hline COD, suspended (filtered $0,45 \mu \mathrm{m}$ ) & & 4 & 143.00 & 25.26 & 0.18 \\
\hline COD, dissolved (filtered 0,45 $\mu \mathrm{m}$ ) & $\mathrm{mg} / \mathrm{l}$ & 4 & 137.25 & 12.26 & 0.09 \\
\hline TOC, dissolved & $\mathrm{mg} / \mathrm{l}$ & 11 & 42.95 & 11.90 & 0.28 \\
\hline TOC, suspended & $\mathrm{mg} / \mathrm{l}$ & 9 & 66.60 & 16.74 & 0.25 \\
\hline TOC, suspended (filtered $0,45 \mu \mathrm{m}$ ) & & 2 & 28.45 & 9.26 & 0.33 \\
\hline TKN (Laton) dissolved & $\mathrm{mg} \mathrm{N} / \mathrm{l}$ & 10 & 45.81 & 13.58 & 0.30 \\
\hline TKN (Laton) suspended & $\mathrm{mg} \mathrm{N} / \mathrm{l}$ & 4 & 56.88 & 29.11 & 0.51 \\
\hline $\mathrm{NH} 4-\mathrm{N}$ dissolved & $\mathrm{mg} \mathrm{N} / \mathrm{l}$ & 26 & 39.54 & 11.56 & 0.29 \\
\hline NO3-N & $\mathrm{mg} \mathrm{N} / \mathrm{l}$ & 8 & 0.42 & 0.09 & 0.23 \\
\hline PO4 & $\mathrm{mg} / \mathrm{l}$ & 17 & 5.42 & 1.81 & 0.33 \\
\hline SO4 disolved & $\mathrm{mg} / \mathrm{l}$ & 4 & 32.35 & 12.16 & 0.38 \\
\hline SO4 suspended & $\mathrm{mg} / \mathrm{l}$ & 1 & 52.40 & & \\
\hline Absorbence, $230 \mathrm{~nm}$ & A.U. & 12 & 0.01 & 0.02 & 2.12 \\
\hline Absorbence, centrifuged, $230 \mathrm{~nm}$ & A.U. & 9 & 0.01 & 0.02 & 2.24 \\
\hline Absorbence, $260 \mathrm{~nm}$ & A.U. & 28 & 0.57 & 0.31 & 0.54 \\
\hline Absorbence, centrifuged, $260 \mathrm{~nm}$ & A.U. & 9 & 0.21 & 0.06 & 0.28 \\
\hline Absorbence, $280 \mathrm{~nm}$ & A.U. & 12 & 0.40 & 0.15 & 0.38 \\
\hline Absorbence, centrifuged, $280 \mathrm{~nm}$ & A.U. & 9 & 0.22 & 0.07 & 0.30 \\
\hline Absorbence, $830 \mathrm{~nm}$ & A.U. & 28 & 0.14 & 0.06 & 0.43 \\
\hline Absorbence, centrifuged, $830 \mathrm{~nm}$ & A.U. & 9 & 0.07 & 0.03 & 0.41 \\
\hline Absorbence, $860 \mathrm{~nm}$ & A.U. & 28 & 0.13 & 0.06 & 0.43 \\
\hline Absorbence, centrifuged, $860 \mathrm{~nm}$ & A.U. & 9 & 0.06 & 0.03 & 0.41 \\
\hline Absorbence, $890 \mathrm{~nm}$ & A.U. & 27 & 0.13 & 0.06 & 0.44 \\
\hline Absorbence, centrifuged, $890 \mathrm{~nm}$ & A.U. & 9 & 0.06 & 0.02 & 0.43 \\
\hline
\end{tabular}




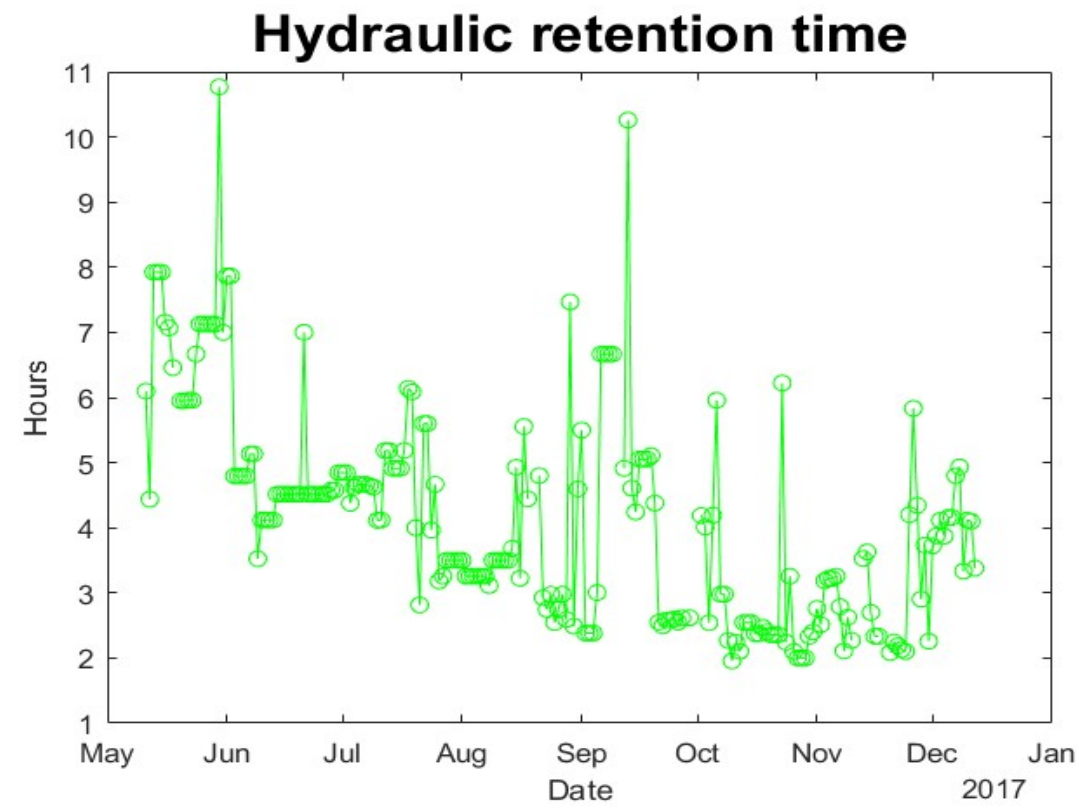

Figure 4 Hydraulic retention time

\section{Solids removal}

The anaerobic filter removed both dissolved and suspended COD. Note that primary sedimentation basin effluent contained more than $60 \%$ ash (non-volatile fraction of total solids).

Table 1 Solids removal

\begin{tabular}{|l|c|c|c|c|c|c|}
\hline Anaerobic filter & & Total solids & Volatile solids & COD, dissolved & COD, suspended & COD, total \\
\hline Influent & $\mathrm{mg} / \mathrm{l}$ & 600 & 222 & 256 & 429 & 685 \\
\hline Effluent & $\mathrm{mg} / \mathrm{l}$ & 500 & 145 & 124 & 223 & 347 \\
\hline Reduction & $\%$ & 17 & 35 & 52 & 48 & 49 \\
\hline
\end{tabular}

Considering that primary sedimentation contains a large fraction of inorganic materials, biological solids removal should be assessed by comparing UAF influent and effluent suspended TOC and suspended TKN. These organic fractions comprise large molecules such as proteins, fats and cellulose. The anaerobic filter removed $46 \%$ of the TOC in suspension and $9 \%$ of the TKN in suspension.

Tableau 1 Suspended COT and TKN removal

\begin{tabular}{|c|c|c|c|c|c|c|c|c|c|c|}
\hline Substance & & 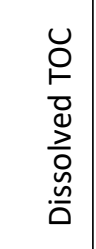 & 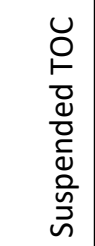 & 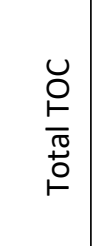 & $\begin{array}{l}z \\
\dot{1} \\
\dot{1} \\
\frac{1}{z}\end{array}$ & $\begin{array}{l}z \\
\dot{1} \\
\text { On } \\
z\end{array}$ & $\begin{array}{l}z \\
\text { ñ } \\
0 \\
z \\
+ \\
z \\
z \\
\dot{1} \\
\dot{1} \\
z\end{array}$ & 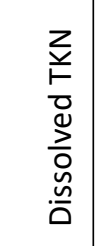 & 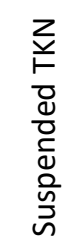 & 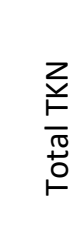 \\
\hline Balance (UAF effluent - UAF influent) & mmoles/l & $-3,1$ & $-4,8$ & $-7,9$ & $-1,0$ & 0,0 & $-1,0$ & $-1,6$ & $-0,4$ & $-2,0$ \\
\hline Balance (UAF effluent - UAF influent) & $\%$ & $-46,8$ & $-46,2$ & $-46,5$ & $-25,6$ & $-33,3$ & $-25,7$ & $-32,5$ & $-9,2$ & $-21,3$ \\
\hline
\end{tabular}

In addition to comparing influent and effluent total solids determined gravimetrically, it is useful to simply observe the dried solids. Influent solids were a dark brown coloured viscous paste. Effluent solids were a light brown coloured sand like powder. As shown in the photo below, solids are removed 
by the anaerobic filter. The solids remaining in the effluent are $71 \%$ non-volatile. The ash fraction cannot be removed biologically. The non-volatile fraction is apparently recalcitrant to biological degradation.

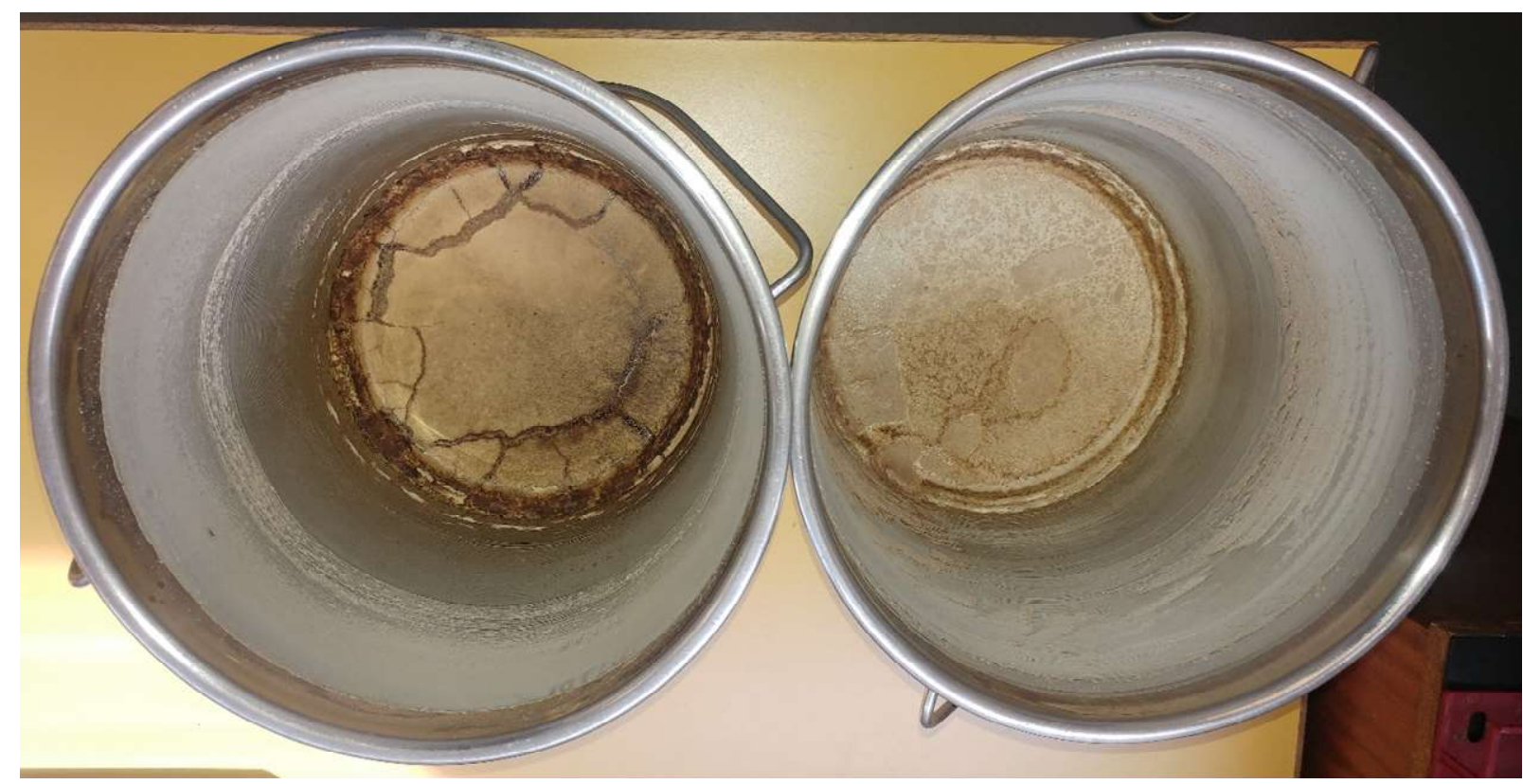

Figure 5 Dried influent (left), dried effluent (right)

\section{FT-IR analysis of total solids}

Influent and effluent liquid samples were dried at $105^{\circ} \mathrm{C}$. The dried solids were ground to obtain a fine powder. FT-IR spectra of the dried solids were obtained and compared to spectral libraries to identify substances present in the dried solids. The method is qualitative and not quantitative. The identified substances can be classified into 3 broad categories:

- Mineral clays

- Benzene and benzene derivatives

- Phosphonium derivatives

All three categories contain chlorinated derivatives. This exploratory study did not reveal a significant difference between the influent and the effluent. An example FT-IR spectrum is given in the figure below. 


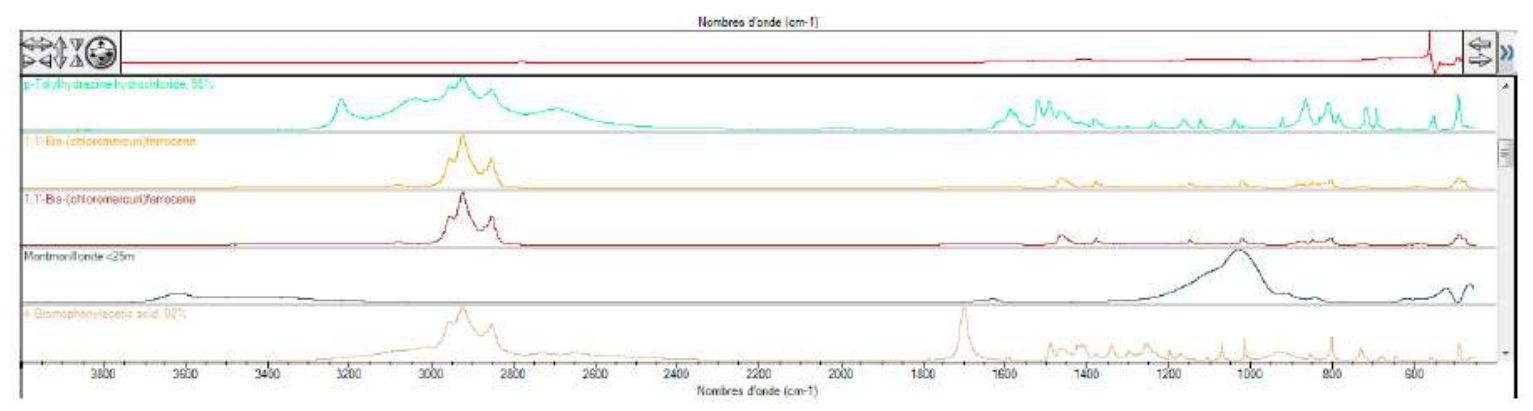

\begin{tabular}{|l|l|l|l|}
\hline & $\begin{array}{l}\text { Correspon } \\
\text { dance }\end{array}$ & Titre & Dossier \\
\hline 1 & 34.58 & Dichloroisopropylphosphine, 97\% & HR Aldrich FT-IR Collection Edition II \\
\hline 2 & 32.33 & Benzene-d6, 100.0 atom \% D & HR Aldrich FT-IR Collection Edition II \\
\hline 3 & 32.33 & Benzene-d6, 100.0 atom \% D & $\begin{array}{l}\text { HR Aldrich Organometallic, Inorganic, } \\
\text { Silanes, Boranes, and Deuterated } \\
\text { Compounds }\end{array}$ \\
\hline 4 & 31.42 & $\begin{array}{l}\text { p-Tolylhydrazine hydrochloride, } \\
98 \%\end{array}$ & HR Aldrich FT-IR Collection Edition II \\
\hline 5 & 30.14 & 1,1 '-Bis-(chloromercuri)ferrocene & $\begin{array}{l}\text { HR Aldrich Organometallic, Inorganic, } \\
\text { Silanes, Boranes, and Deuterated } \\
\text { Compounds }\end{array}$ \\
\hline
\end{tabular}

Figure 6 Substances identified in dried solids by FT-IR

\section{Biofilm assessment}

The presence of a biofilm and biofilm activity were assessed using three methods

- Aldehyde dehydrogenase activity

- ATP concentration

- Scanning electron microscopy

Aldehyde dehydrogenase activity

The oxidation of organic compounds is a dehydrogenation process mediated by specific dehydrogenase enzymes. Therefore, The Dehydrogenase Enzyme Activity (DHA) reflects microbial activity. The DHA assay is based on the reaction of redox-sensitive tetrazolium indicators. Triphenyl tetrazolium chloride (TTC) compounds are colourless and, after reduction, they are transformed into water insoluble, red coloured mono-formazans (TPF), which can be quantified by spectrophotometry. The DHA activity assay was adapted to the conditions of the AFBR project by a student intern and used to assess biofilm support materials including the torrefied chips, plastic foam and hard plastic supports. The samples were placed in the AFBR for between 15 and 98 days and then removed for assessment of biofilm activity. Biofilm specific activity can be expressed in terms of TPF $/ \mathrm{m}^{2}$ support surface. The highest biofilm specific activity was measured on the polyurethane foam supports. The activity measured using the ADH assay was 5 times greater on the polyurethane foam supports than the activity measured on the next best performing supports (some types of hard plastics and torrefied wood chips). The activity of biofilms that developed on torrefied wood was the same or higher than almost all the hard plastic supports.

ATP concentration and UV measurements

The concentration of ATP is positively correlated with the number of bacteria. The number of bacteria per volume of biofilm support can be evaluated by determination of ATP. Biofilm coated chips were 
removed from the AFBR and ground to dislodge the bacteria. The total ATP concentration [TATP] of the suspension was measured and then divided by the measured volume of chips. The anaerobic filter biofilm concentration factor is defined as follows:

Biofilm concentration factor $=$ tATP on supports/tATP in the bulk water

\begin{tabular}{|l|c|}
\hline Sample number & tATP $[\mathrm{ng} / \mathrm{ml}]$ \\
\hline 1 & 81.95 \\
\hline 2 & 111.1 \\
\hline 3 & 105.2 \\
\hline Mean & 99.4 \\
\hline & \\
\hline AFBR Influent & 30.2 \\
\hline AFBR Effluent & 31.4 \\
\hline & \\
\hline Biofilm concentration factor & 3.2 \\
\hline
\end{tabular}

Table 2 total ATP determinations

Biofilm concentration factor $=99.4[\mathrm{ng} / \mathrm{ml}] / 30.8[\mathrm{ng} / \mathrm{ml}]=3.2$

The concentration of ATP measured on the biofilm support was 3.2 times greater than the concentration measured in both the influent and the effluent. The increase in the bacterial concentration between the influent and effluent streams was $4 \%$ (one measurement). This result demonstrates that a biofilm did develop on the torrefied wood chips and that it does not release bacteria to the effluent at a rate that is greater than the rate of bacteria introduction to the AFBR via the influent.

UV measurement

UV measurements at $280 \mathrm{~nm}$ give an indication of the protein content of the water and measurements at $260 \mathrm{~nm}$ indicate the DNA content. DNA content is correlated with the presence of microorganisms. Measurements of the influent and the effluent showed that both protein and DNA content decrease in the AFBR supporting the conclusion that the biofilm is attached to the filter bed and that the AFBR removes protein and DNA.

\section{Scanning electron microscopy}

The scanning electron micrographs made during a previous study conducted in the same AFBR also using torrefied wood chip biofilm supports but fed dairy wastewater and not municipal primary effluent are shown below. The biofilm is present after 4 months of continuous operation. However, the surface is not entirely covered. The surface coverage and consequently the total biological activity is expected to increase with longer incubation times and increased total biofilm surface coverage. 

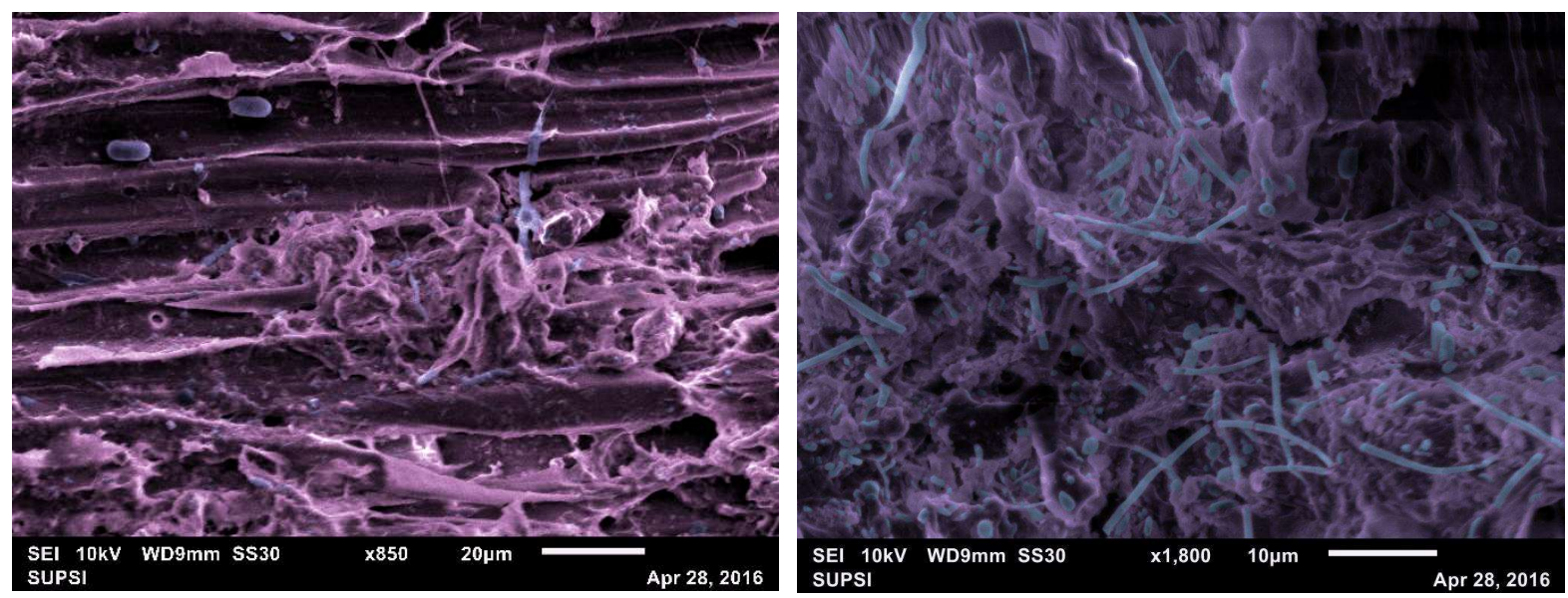

Figure 7 Scanning electron micrographs of biofilms on torrefied wood chips

\section{Impact on carbon supply for denitrification}

The loss of TOC in the UAF might result in insufficient dissolved TOC for the downstream denitrification process. This risk was evaluated by comparing the measured concentrations to the theoretical TOC requirement for denitrification.

The theoretical stoichiometric carbon requirement for denitrification is obtained from the equation below ${ }^{1}$ and the measured $\mathrm{TKN}+\mathrm{NO}_{3}$. Prior conversion of $\mathrm{NH}_{4}-\mathrm{N}$ to $\mathrm{NO}_{3}-\mathrm{N}$ is assumed.

$\mathrm{NO}_{3}+1,08 \mathrm{CH}_{3} \mathrm{OH}+\mathrm{H}+>0,065 \mathrm{C}_{5} \mathrm{H}_{7} \mathrm{O}_{2} \mathrm{~N}+0,47 \mathrm{~N}_{2}+0,76 \mathrm{CO}_{2}+2,44 \mathrm{H}_{2} \mathrm{O}$

If the difference between the dissolved TOC and the theoretical carbon requirement and is less than zero, then carbon will have to be added to the dentrification process. The difference and the ratio of $\mathrm{C} / \mathrm{N}$ in the primary sedimentation basin effluent (UAF influent) were evaluated and are presented in the table below.

Table 3 UAF influent TOC and N ratio

\begin{tabular}{|c|c|c|c|c|c|c|c|c|c|c|}
\hline $\begin{array}{l}\text { Anaerobic filter (UAF) } \\
\text { Stream characteristics }\end{array}$ & & 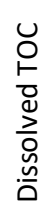 & 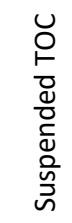 & 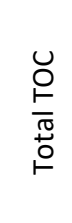 & $\begin{array}{l}z \\
\dot{1} \\
\dot{1} \\
\dot{z}\end{array}$ & $\begin{array}{l}z \\
z_{1} \\
\text { On } \\
z\end{array}$ & $\begin{array}{l}z \\
\dot{1} \\
\text { On } \\
2 \\
+ \\
z_{1} \\
\dot{1} \\
\frac{1}{z}\end{array}$ & 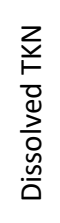 & $\begin{array}{l}z \\
\frac{z}{1} \\
\frac{0}{d} \\
\frac{d}{0} \\
\frac{0}{d} \\
\frac{0}{0} \\
\bar{n}\end{array}$ & 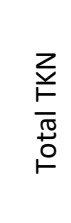 \\
\hline Influent & $\mathrm{mg} / \mathrm{l}$ & 80, & 123, & 204, & 53, & 0 , & 53, & 67, & 62 , & 130, \\
\hline Influent & mmoles/l & 6,7 & 10,3 & 17,0 & 3,8 & 0 , & 3,8 & 4,8 & 4,5 & 9,3 \\
\hline TOC requirement for conversion & mmoles/l & & & & 4,1 & 0, & 4,1 & 5,2 & 4,8 & 10,1 \\
\hline Balance (Influent dissolved TOC - Required TOC) & mmoles/l & 2,6 & & & & & & & & \\
\hline Ratio $\mathrm{C} / \mathrm{N}$ dissolved & moleC/moles & 1,4 & & & & & & & & \\
\hline Ratio $\mathrm{C} / \mathrm{N}$ total & moleC/moles & 1,8 & & & & & & & & \\
\hline
\end{tabular}

Based on the averages of the entire study duration, the difference between the concentration of dissolved TOC in the influent and the TOC requirement for conversion of nitrate obtained from influent

\footnotetext{
${ }^{1}$ Metcalf \& Eddy, Wastewater Engineering, Third edition, 1991
} 
ammonium is 2,6 mmols/l. In the studied primary effluent stream, the balance in positive and the ratio is favorable for downstream denitrification.

However, as shown below, the UAF increases the risk of a lack of carbon for downstream denitrification. The difference between the concentration of dissolved TOC in the influent and the TOC requirement for conversion of nitrate obtained from influent ammonium is only $0.5 \mathrm{mmols} / \mathrm{l}$. The reduced $\mathrm{C} / \mathrm{N}$ ratios of the UAF effluent streams confirm this risk. This result is an important argument against implementation of UAF treatment of primary effluent in a conventional wastewater treatment plant with denitrification. As a pre-treatment implemented at some sites in a regional network, the impact of the carbon loss is reduced because some streams will not be treated by UAF.

Table 4 Impact on denitrification

\begin{tabular}{|c|c|c|c|c|c|c|c|c|c|c|}
\hline $\begin{array}{c}\text { Downstream } \\
\text { denitrification process }\end{array}$ & & 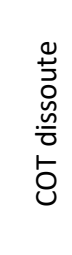 & 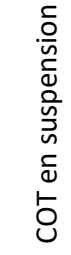 & $\begin{array}{l}\frac{0}{\pi} \\
\stackrel{0}{0} \\
\stackrel{5}{0}\end{array}$ & $\begin{array}{l}z \\
\dot{1} \\
\dot{1} \\
\mathbf{z}\end{array}$ & $\begin{array}{l}z \\
\dot{n} \\
\text { Oे } \\
\text { z }\end{array}$ & $\begin{array}{l}z \\
1 \\
\text { m } \\
0 \\
\sum_{2} \\
+ \\
z_{1} \\
\dot{1} \\
\frac{1}{z}\end{array}$ & 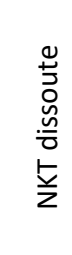 & $\begin{array}{l}\frac{c}{0} \\
\frac{0}{n} \\
\frac{1}{d} \\
\frac{0}{n} \\
\bar{n} \\
\frac{c}{d} \\
\frac{5}{z}\end{array}$ & 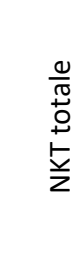 \\
\hline Influent & $\mathrm{mg} / \mathrm{l}$ & 43,0 & 66,6 & 109,6 & 39,5 & 0,4 & 40,0 & 45,8 & 56,9 & 102,7 \\
\hline Influent & mmoles/l & 3,6 & 5,6 & 9,1 & 2,8 & 0,0 & 2,9 & 3,3 & 4,1 & 7,3 \\
\hline Carbon requirement & mmoles/l & & & & 3,1 & 0,0 & 3,1 & 3,5 & 4,4 & 7,9 \\
\hline Balance (TOCdis $-\mathrm{C}$ required) & mmoles/l & 0,5 & & & & & & & & \\
\hline Ratio $\mathrm{C} / \mathrm{N}$ dissolved & moleC/moles N & 1,1 & & & & & & & & \\
\hline Ratio $\mathrm{C} / \mathrm{N}$ total & moleC/moles $\mathrm{N}$ & 1,2 & & & & & & & & \\
\hline
\end{tabular}

\section{Digester temperature}

Type $\mathrm{K}$ thermal couples were used to measure the temperatures of the:

- Inlet stream

- Centre of the anaerobic filter

- Outlet stream

- Ambient air

The AFBR digester is equipped with a concentric water jacket that was used to attempt to maintain a constant temperature inside the AFBR. However, it was not possible to cool the digester during hot summer days and it was not possible to adequately heat the digester when the flow rate was high and the water temperature was low.

The difference in temperature between the thermocouple placed at the center of the digester and a hand-held temperature probe used to control the temperature on 3 different days was between -0.8 and $+2.4^{\circ} \mathrm{C}$. Consequently, the reported temperature of the anaerobic filter bed (digester) is believed to be within $3^{\circ}$ of the true value. The temperature set points during the experiment are shown in Table 5 Digester temperature set points:

\begin{tabular}{|l|c|c|c|}
\hline \multicolumn{1}{|c|}{ Dates } & Number of days & Temperature set point $\left[{ }^{\circ} \mathbf{C}\right]$ & Average digester temperature $\left[{ }^{\circ} \mathbf{C}\right]$ \\
\hline June $28^{\text {th }}$ to August $19^{\text {th }}$ & 52 & Not heated & 27 \\
\hline August $20^{\text {th }}$ to September $19^{\text {th }}$ & 31 & $25^{\circ} \mathrm{C}$ & 23 \\
\hline September $20^{\text {th }}$ to November $8^{\text {th }}$ & 50 & $20^{\circ} \mathrm{C}$ & 20 \\
\hline November $9^{\text {th }}$ to December $15^{\text {th }}$ & 38 & Not heated & 13 \\
\hline
\end{tabular}

Table 5 Digester temperature set points 
One of the main results of this study was the demonstration of stable operation in different temperature intervals. Nevertheless, biogas production decreased towards the end of the study after the influent temperature decreased to less than $16^{\circ} \mathrm{C}$. Between November 2017 and March 2018, the measured wwtp primary effluent temperature was most often between 14 and $20^{\circ} \mathrm{C}$. The temperature was below $15^{\circ} \mathrm{C}$ for only short durations and almost never was below $10^{\circ} \mathrm{C}$. These results and observations suggest that the AFBR concept can be usefully applied to treat un-heated wastewater in temperate climates.

\section{Biogas production}

Both biogas and liquid effluent exited the bioreactor via the same tube that was connected to a closed decanter that served as a gas/liquid/solids separator. Biogas exited the decanter head space through a $4 \mathrm{~mm}$ tube. A very small headspace pressure of $\sim 2$ mbars was maintained by immersion of the biogas exit tube to $20 \mathrm{~mm}$ below the water surface of a bottle that served as a biogas check-valve. Biogas exited the check-valve bottle via a $4 \mathrm{~mm}$ tube that carried the biogas to an on-line analyser comprising flow through $\mathrm{CH}_{4}$ measurement (IR) and a mass flow meter (thermal mass principle) calibrated with a mixture of $60 \% \mathrm{CH}_{4}$ and $40 \% \mathrm{CO}_{2}$ and sampled every second. The biogas entered the gas analyser in pulses corresponding to the biogas bubbles observed in the water trap. Existing lab instruments were used during the pilot study for biogas quantification and composition. It was not possible to make accurate flow rate and methane concentration measurements during the pilot study. The mass flow meter requires a flow rate of at least $500 \mathrm{ml} / \mathrm{min}$ to measure accurately. This flow rate was not attained regularly. When there was no biogas flow, the biogas in the methane measuring cell was diluted with ambient air. Since biogas flowed in irregular pulses, only the peak methane concentrations should be considered as valid measurements. Although there are major deficiencies in the technique used during this exploratory study, the approaches used made it possible to quantitatively and to qualitatively assess biogas production.

\section{Quantity of biogas produced}

Three methods were used to estimate the methane production.

1. Calculation of total biogas volume flow by integration of the area under the mass flow rate curve. The error of this method is due to variations in the gas composition and to the actual flow rate being less than the minimum flow rate required by the manufacturer of the mass flow meter. The advantage of this method is that variations during the day can be monitored because the gas flow rate is recorded every second.

2. Calculation of methane production from the difference in the higher heating value of the solids contained in the influent and the effluent. The error of this method is due the fact that not all the chemical energy lost is transformed into methane.

3. Calculation of methane production from the difference in the volatile solids content of the solids contained in the influent and the effluent. The error of this method is due to inaccuracy of volatile solids determinations and lack of knowledge the biogas yield from volatile solids.

4. Calculation of methane production from the difference in the COD content of the influent and the effluent. The error of this method is due the fact that not all the COD lost is transformed into methane.

The average daily methane production rate determined using these 4 methods is presented in table.

\begin{tabular}{|l|c|c|c|}
\hline Method & Mean $\mathbf{C H}_{4}$ production [N & RSD [\%] & Remark \\
\hline Mass flow & 6 & & Assume $65 \% \mathrm{CH}_{4}$ content of biogas \\
\hline HHV removal & 20 & 42.5 & $36 \mathrm{MJ}^{3} \mathrm{CH} 4$ \\
\hline COD removal & 29 & 28 & Assume $0,35 \mathrm{~m}^{3} \mathrm{CH}_{4} / \mathrm{kg}$ COD removed \\
\hline
\end{tabular}




\begin{tabular}{|l|l|l|l|}
\hline VS removal & 17 & 69 & Assume $0,6 \mathrm{~m}^{3} \mathrm{CH}_{4} / \mathrm{kg} \mathrm{VS} \mathrm{removed}$ \\
\hline
\end{tabular}

Table 6 Rate of methane production

\section{Quality of biogas produced}

Biogas components were also measured on 3 different days using a multigas detector that sucked biogas from the head space. The gas detector was designed for security and not for analytical use. The measured values are reported in the table.

\begin{tabular}{|c|c|c|}
\hline Biogas component & Unit & Measured values \\
\hline $\mathrm{CH}_{4}$ & \% volume & $67,79,76$ \\
\hline $\mathrm{H}_{2}$ & $\mathrm{ppm}$ & $4,12,3$ \\
\hline $\mathrm{H}_{2} \mathrm{~S}$ & $\mathrm{ppm}$ & $56,373,>500$ \\
\hline $\mathrm{NH}_{3}$ & $\mathrm{ppm}$ & $3,77,31$ \\
\hline
\end{tabular}

The methane concentration values measured on-line using the IR flow through cell were regularly $10 \%$ volume less than the values measured using the multigas detector. Consequently, the actual methane value is assumed to be at least $5 \%$ greater than the reported on-line measurement value.

The methane content of the produced biogas was consistently superior to $60 \%$ volume and frequently superior to $70 \%$ volume.

\section{Robustness}

The biological activity of the anaerobic filter is the result of a biofilm that developed on the torrefied wood chip support. Due to the presence of extracellular polymer support matrices and to microbial consortiums, biofilms are known to be more resistant to chemical and hydraulic variations than suspended growth cultures. The tests of biological robustness of the anaerobic filter bioreactor and the range of values tested are.

\begin{tabular}{|l|c|}
\hline Variable influent parameter & Range of variation \\
\hline Flow rate $[\mathrm{l} /$ day $]$ & 0 to 516 \\
\hline Influent temperature $\left[{ }^{\circ} \mathrm{C}\right]$ & 8 to 40 \\
\hline COD load $[\mathrm{kg} \mathrm{COD} / \mathrm{m} 3 /$ day] & 1 to 6 \\
\hline
\end{tabular}

Table 7 Range of important variable influent parameters

The variations in all the measured parameters are presented graphically on request. The general conclusions are that the AFBR is resistant to the tested:

- Influent flow rate variations

- Temperature variations. However, biogas productivity declined as the average temperature declined.

- COD load variations

- Influent nutrient variations 


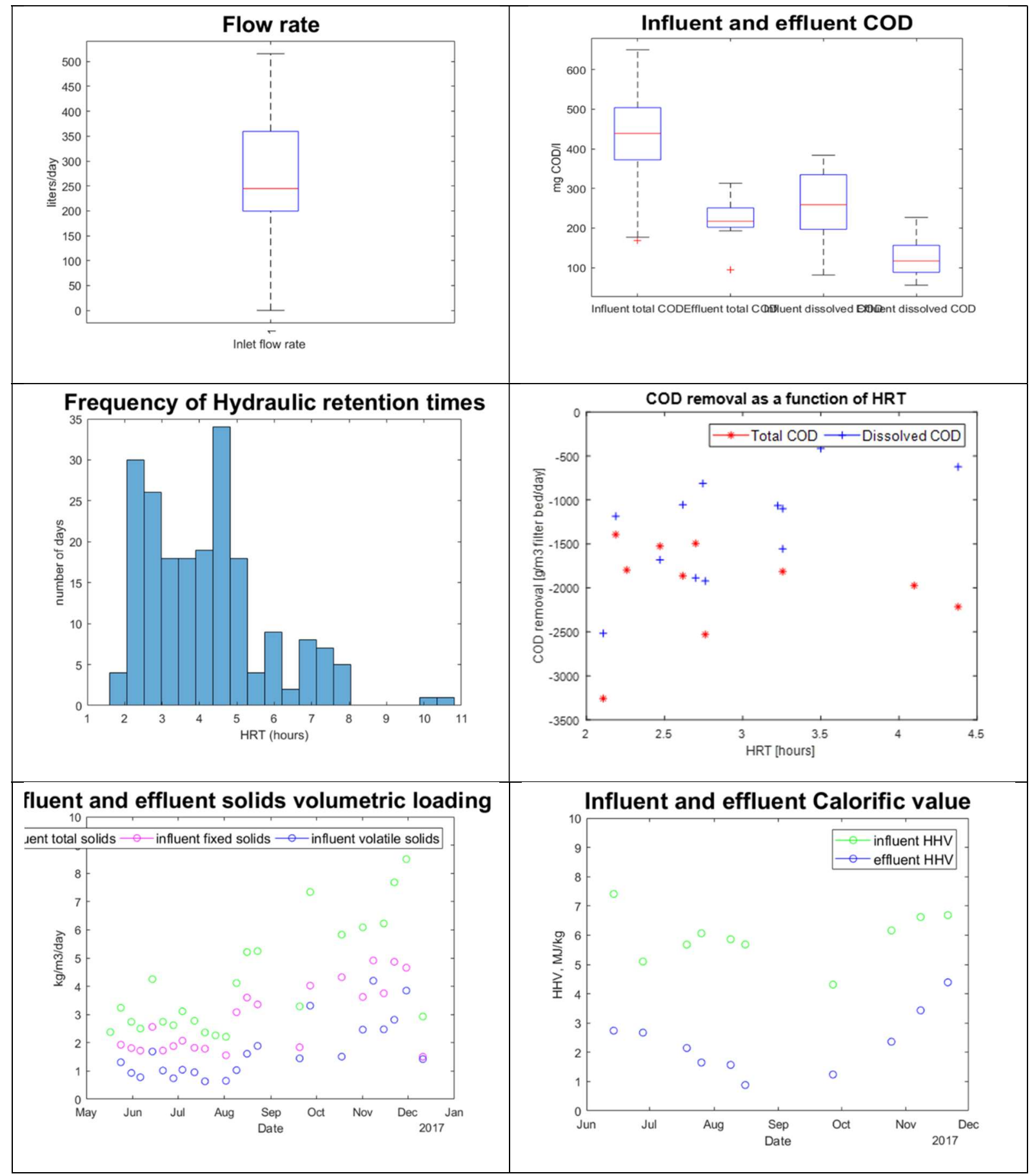




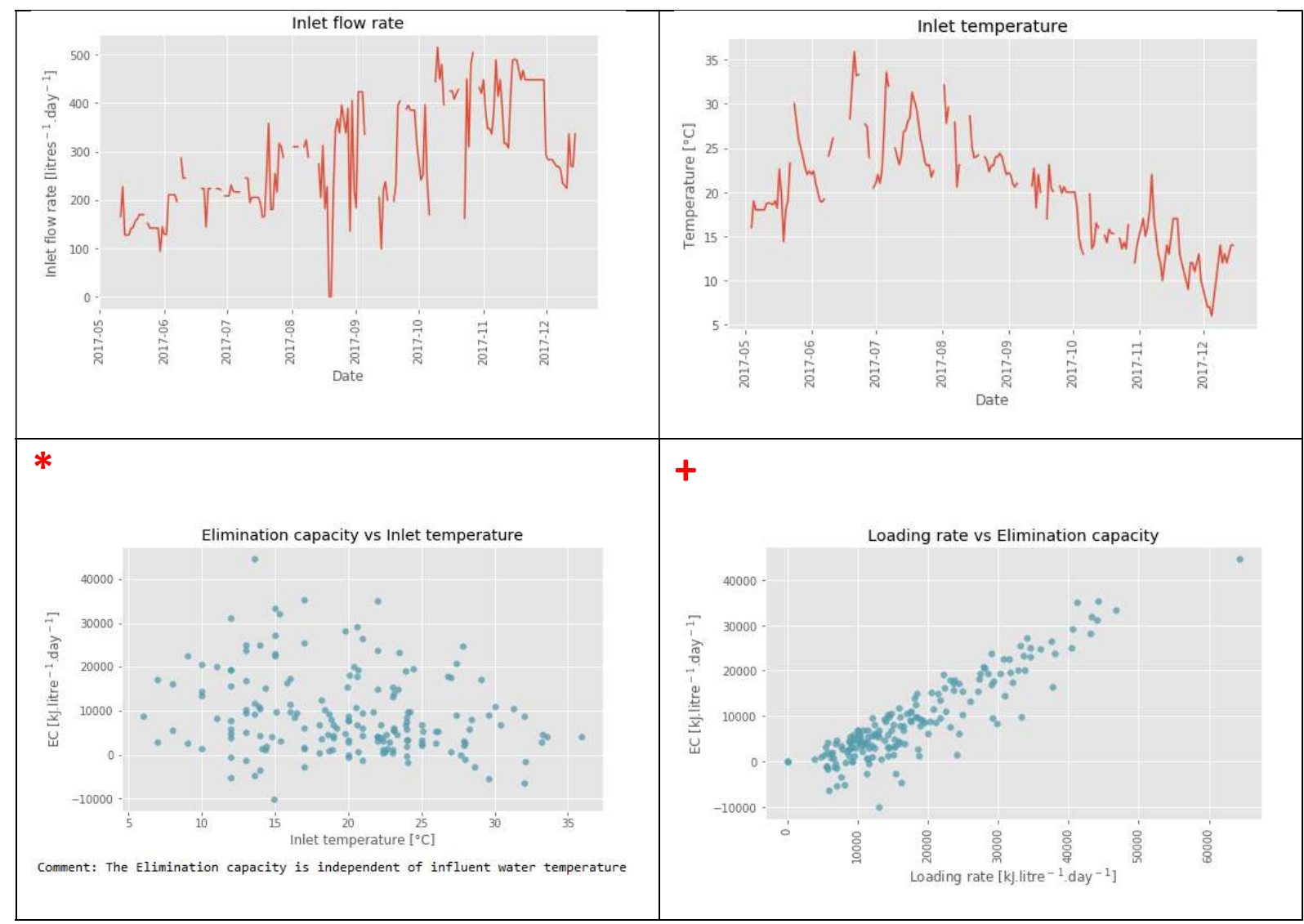

* Elimination capacity $(E C)=(H H V i n-H H V o u t) /$ UAF working volume/day.

This result demonstrates that the process was effective at influent temperatures between 12 and $28^{\circ} \mathrm{C}$. This is the range of normal sedimentation basin effluent in temperate climates. $90 \%$ of the $\Delta H H V$ values were obtained using a fitted equation derived from measured temperature and solids calorific value.

+ Loading rate in terms of influent solids calorific value. The observation that the EC increases with loading rate demonstrates that the UAF was not overloaded.

\section{AFBR Residence Time Distribution}

Efficient use of the AFBR volume requires dispersion of the influent substances (substrate) throughout the filter bed volume. Interpretation of time series plots of the effluent concentration following pulse injection of a tracer substance gives useful information about dispersion and the effectiveness of a packed bed column like the AFBR. Ideally, the substrate will be dispersed across the entire width of the filter bed and advance as a plug to the effluent side thereby allowing the greatest exposition to the biofilm and the longest reaction time. Comparison of the ideal effluent conductivity curve of an ideal plug flow reactor to the actual conductivity curve gives an indication of the effectiveness of substrate dispersion in the anaerobic filter.

The distribution of substrate in the anaerobic filter was assessed by conducting a residence time distribution study of a concentrated salt solution injected as a pulse immediately upstream of the 
anaerobic filter bioreactor ${ }^{2}$. Effluent salt concentration was quantified by conductivity measurements of the AFBR effluent stream. The effluent conductivity profile was compared to an ideal profile. Residence time distribution curves were obtained for six separate injections of salt solutions into the AFBR.

According to chromatography theory, a theoretical plate is described by the time that it takes for solute to equilibrate between a mobile and a stationary phase ${ }^{3}$ and the number of theoretical plates is a function of the retention time and the width of the effluent peak ${ }^{4}$.

$$
N \approx 5,54\left(\frac{V_{r}}{W_{h}}\right)^{2}
$$

$\mathrm{N}=$ Number of theoretical plates

$\mathrm{V}_{\mathrm{r}}=$ Peak retention time

$\mathrm{W}_{\mathrm{h}}=$ Peak width at half peak height

Since efficient use of the anaerobic filter also involves distribution of substrate and contact with a biofilm that is attached to solid packing media, these concepts also apply to an anaerobic filter bioreactor. The data obtained from the experiments was also used to determine the theoretical plate height and optimum mobile phase flow rate.

The range of hydraulic retention times tested was chosen to correspond with the hydraulic retention times tested in the AFBR at the wastewater treatment plant between May and December 2017. After observing that the conductivity profiles corresponded with a well-mixed plug-flow reactor, shorter hydraulic retention times were tested to find the optimum.

The conditions are summarized in the table below and the results are presented in the following tables and graphs.

\begin{tabular}{|l|l|c|}
\hline Anaerobic filter bed volume & liters & 42 \\
\hline Total bioreactor liquid volume & liters & 37 \\
\hline Flow rate & I/h & 7,6 to 90,4 \\
\hline Hydraulic retention time (based on total liquid volume) & hours & 0,41 to 4,8 \\
\hline Salt introduction (dissolved in 1.1 liters water) & grams & 360 \\
\hline Table 8 RTD study conditions
\end{tabular}

Table 8 RTD study conditions

\footnotetext{
${ }^{2}$ Smith, Elliot and James. Characterisation of mixing patterns in an anaerobic digester by means of tracer curve analysis. Ecological Modelling, 69 (1993) 267-285.

${ }^{3}$ https://teaching.shu.ac.uk/hwb/chemistry/tutorials/chrom/chrom1.htm. Accessed April 2018.

${ }^{4} \mathrm{GE}$ column efficiency testing brochure, Application note 28-9372-07 AA.
} 


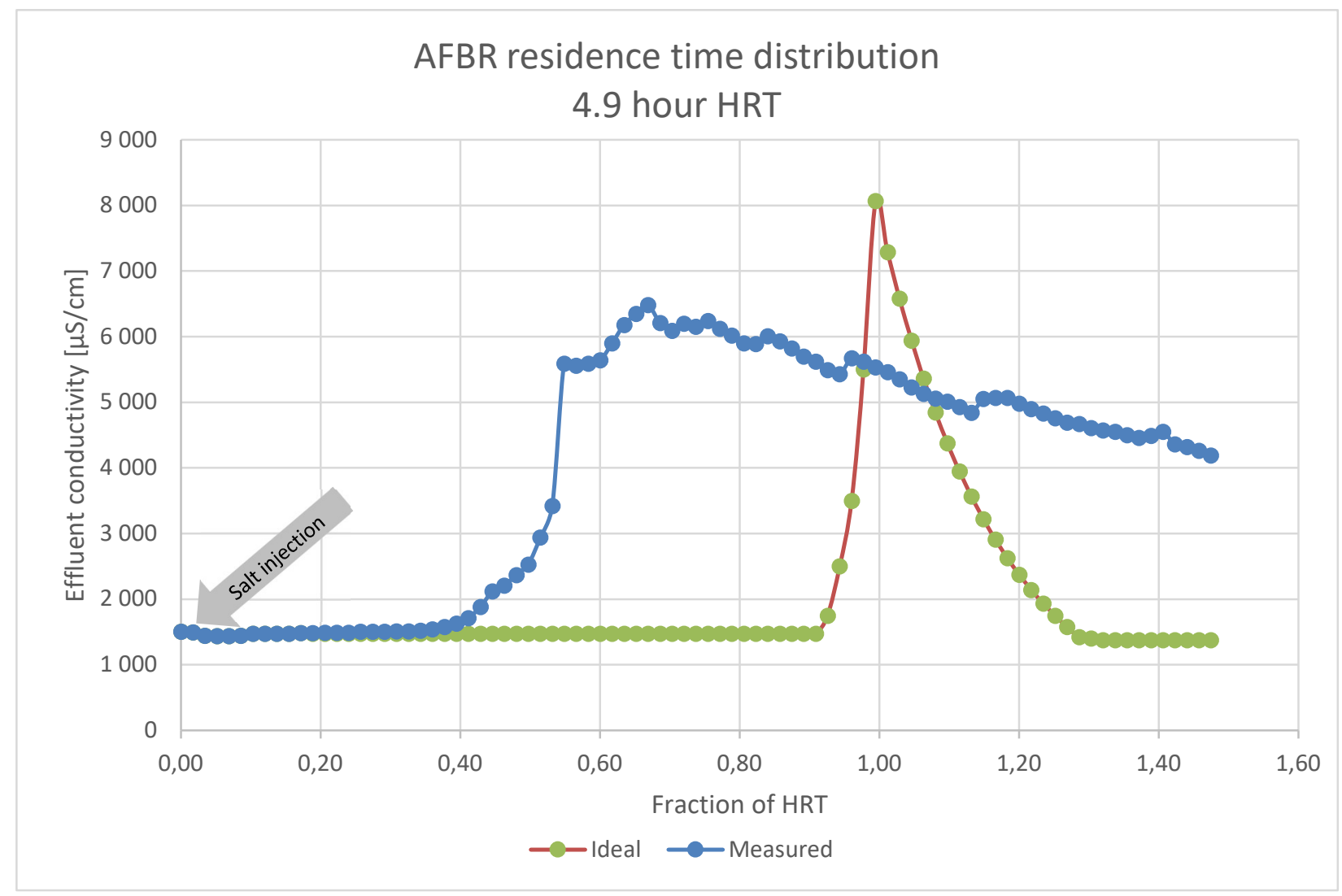

Figure 8 RTD 4.9 h HRT

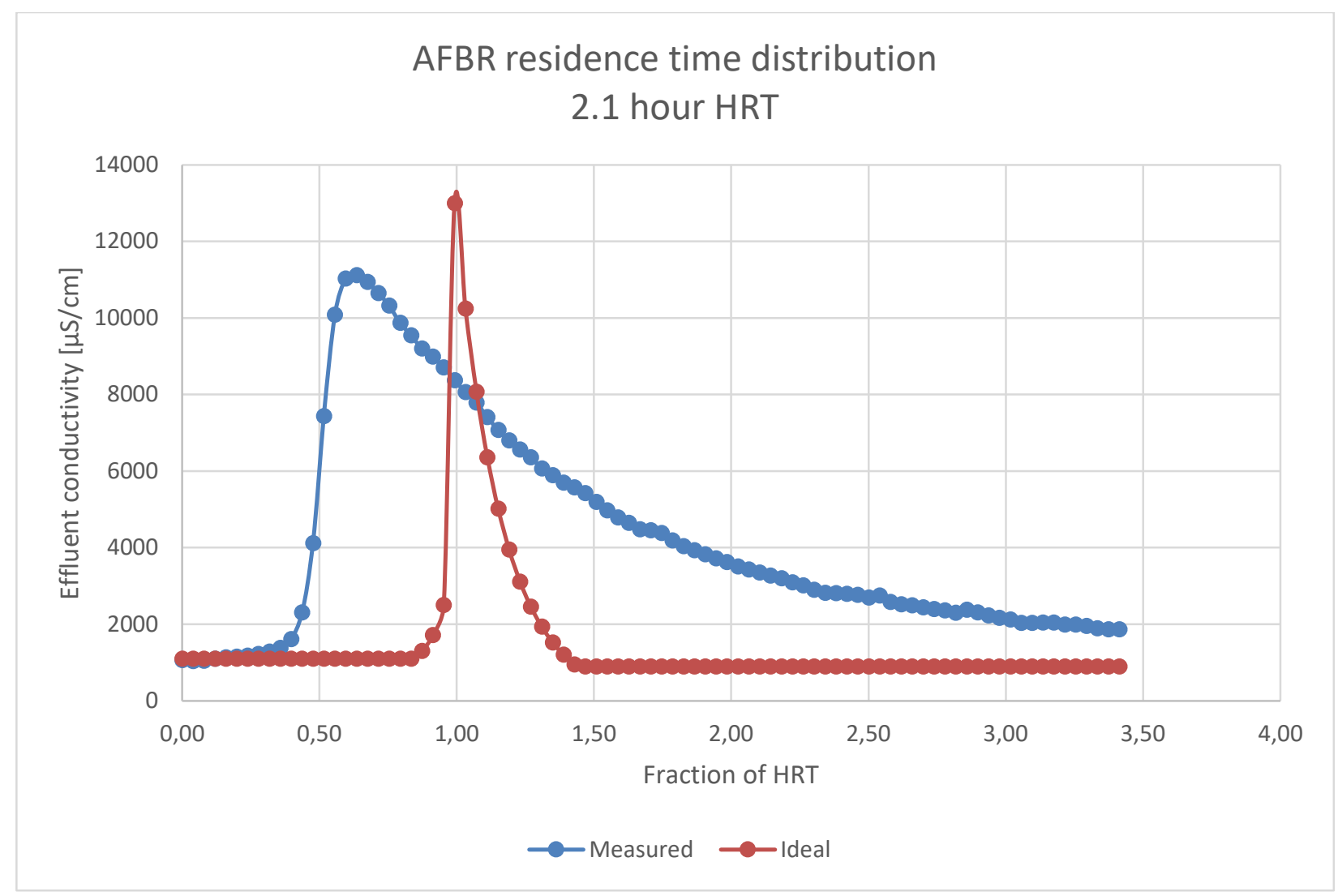

Figure 9 RTD $2.1 \mathrm{~h} H R T$ 


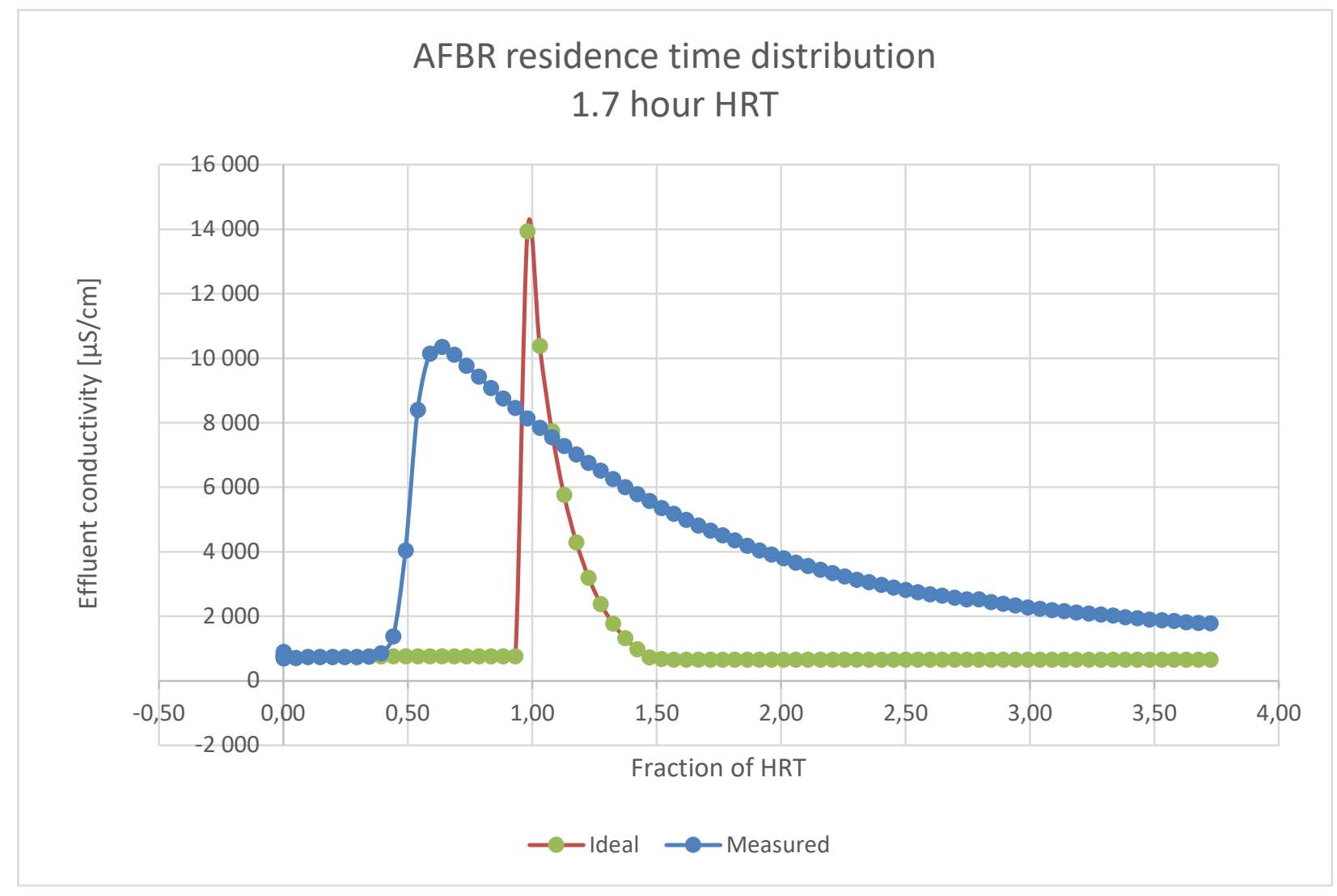

Figure 10 RTD 1,7 h HRT

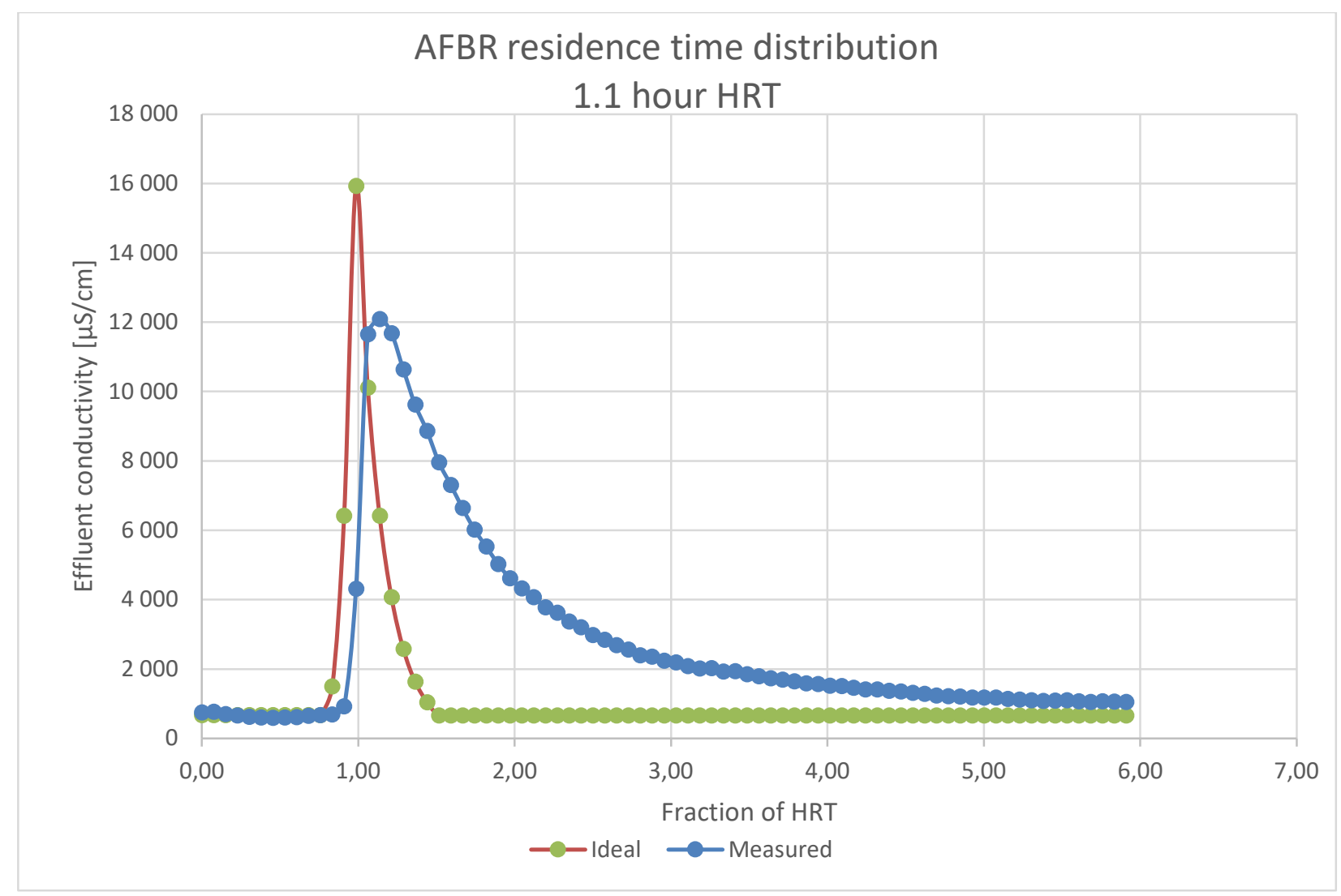

Figure 11 RTD 1,1 h HRT 


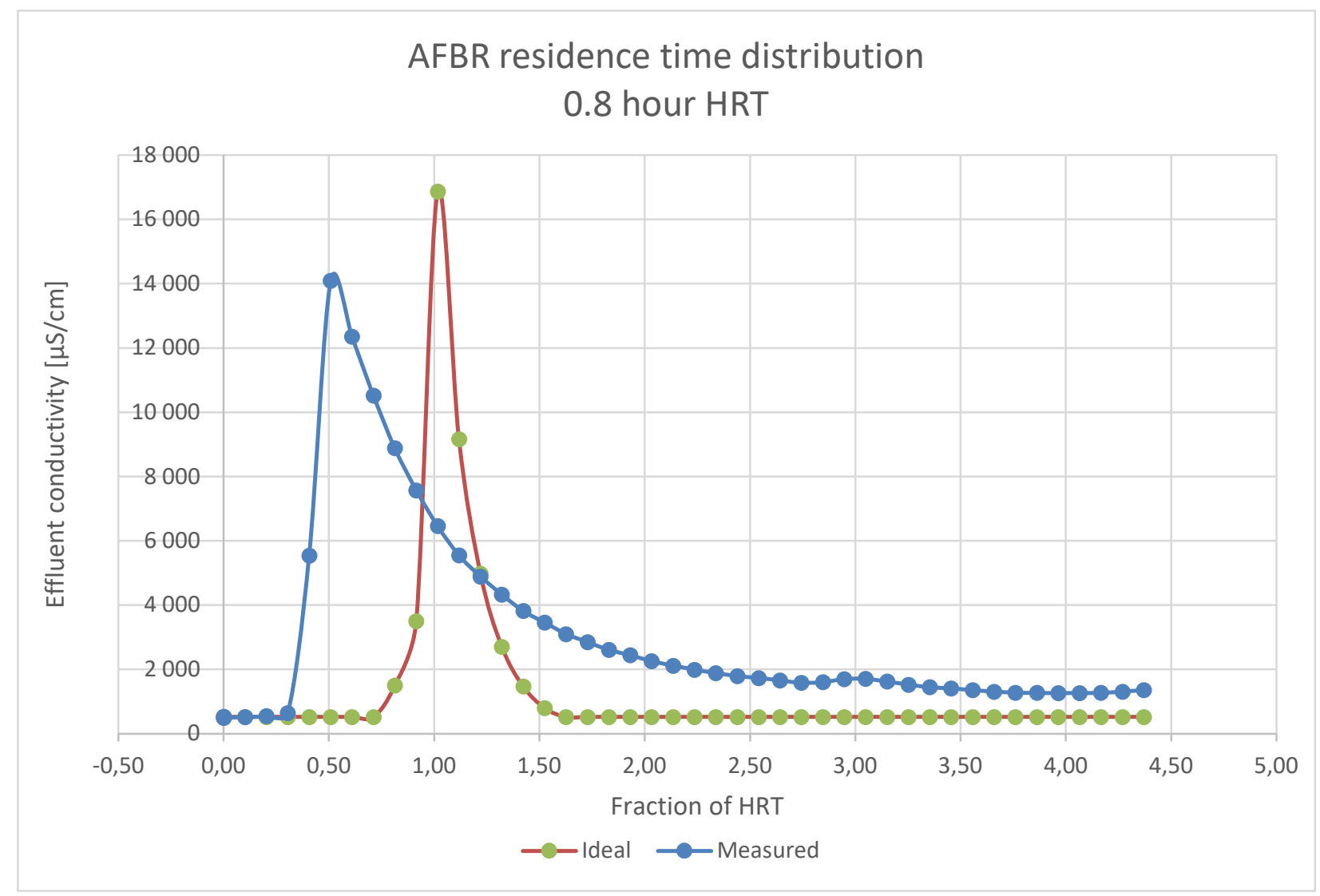

Figure 12 RTD 0,8 h HRT

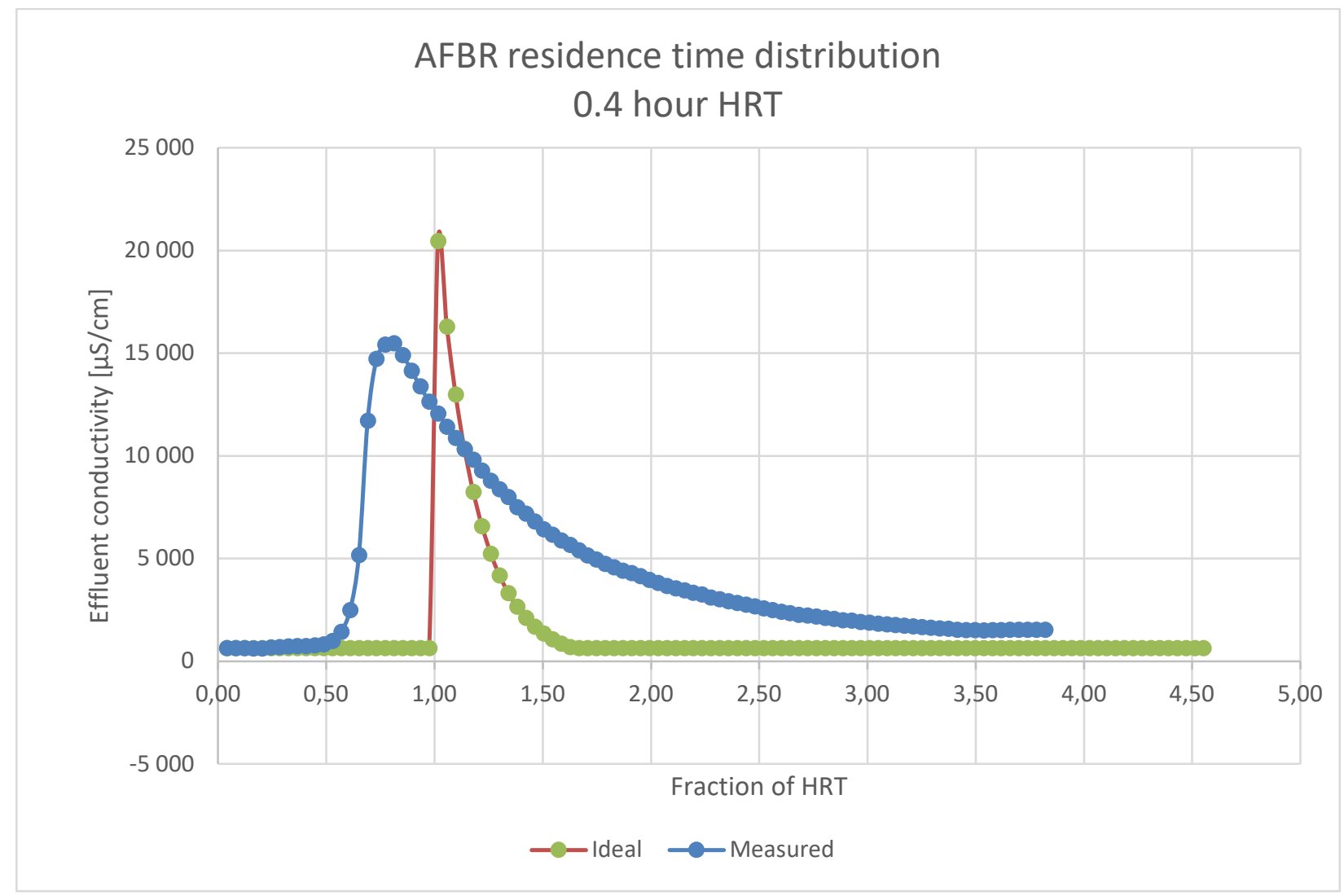

Figure 13 RTD 0,4 h HRT 
In the case of a long hydraulic retention time of 4.9 hours, the concentration rises slowly after only 2.5 hours, then abruptly, and then tails off slowly. The slow initial rise indicates short-circuiting. The abrupt rise indicates plug flow behaviour. The appearance of the first peek after only 0.5 HRTs indicates that the effective volume of the experimental AFBR is less than the actual volume. The absence of a narrow peek and the very slow tailing off indicates the presence of dead zones from which salt continues to diffuse during a prolonged period after reaching a peak concentration in the effluent. The conclusion is that the long HRT leads to the creation of short circuits, dead zones, and the inefficient use the anaerobic filter bed volume.

In the case of short hydraulic retention time of 2.1 hours, the concentration rises abruptly after 1.3 hours and then tails off slowly. The abrupt rise indicates plug flow behaviour as expected. The appearance of the first peak after only 0.8 HRTs indicates that the effective volume of the experimental AFBR is less than the actual volume. The slow tailing off indicates the presence of dead zones from which salt continues to diffuse during a prolonged period after reaching a peek concentration in the effluent. The tests at 0,8 ant 0,4 hours HRT show similar narrow peeks that arrive before the theoretical HRT. Only the test of a 1.1-hour HRT gave a result where the conductivity peak corresponded with the theoretical HRT. The conclusion is that the short HRT leads to more effective mixing of the substrate and efficient use the bioreactor volume with a 1.1 hour HRT being the best for this particular anaerobic filter. In a future project the hydrodynamics should be optimized, and the HRT reduced to less than 3 hours.

In column chromatography, the height equivalent of a theoretical plate (HETP) is a function of the hydraulic retention time, the RTD curve width and the bed length. The Van Deempter plot is used to compare the HETP to the mobile phase velocity at different hydraulic retention times. The most efficient use of the bed volume is attained the minimum of the curve.

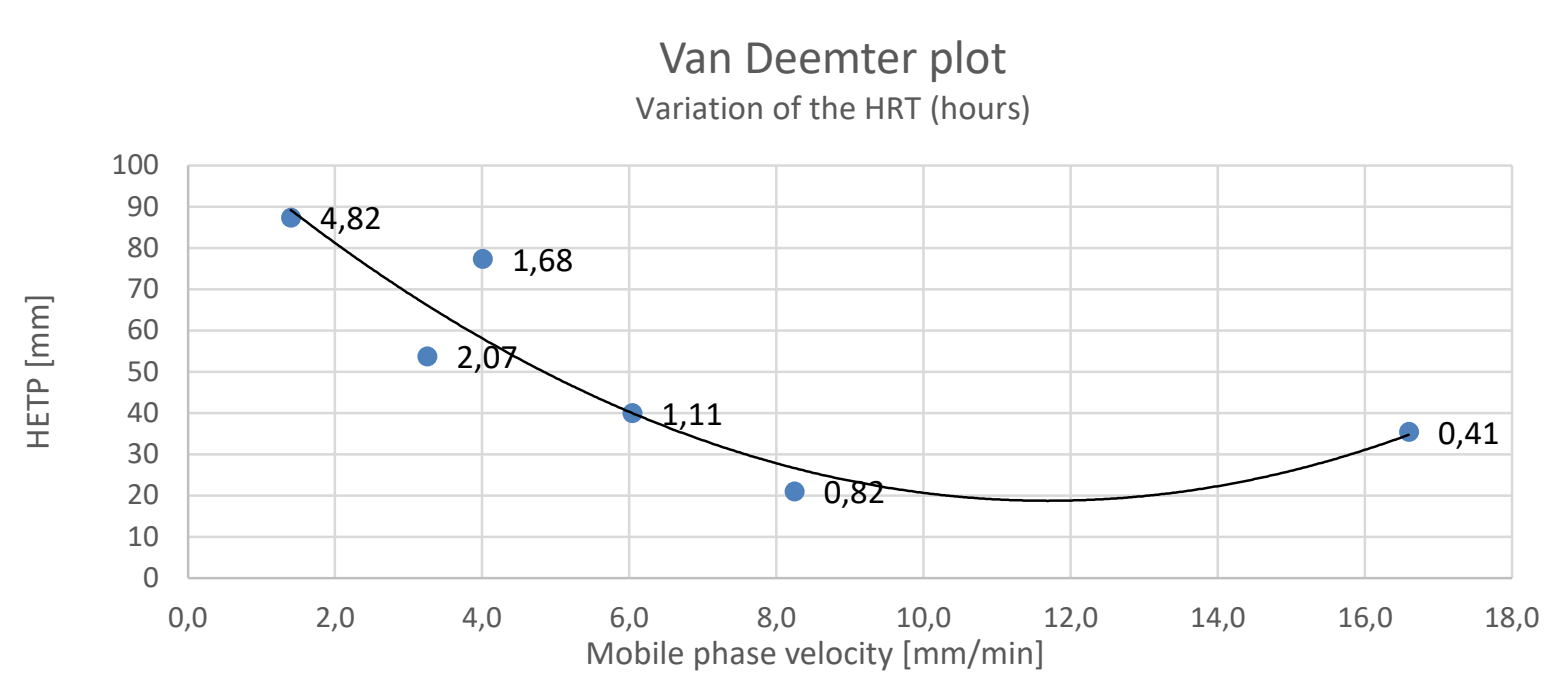

Figure 14 Van Deemter plot

\begin{tabular}{|l|c|c|c|c|c|c|c|}
\hline Tested HRT & hours & $\mathbf{0 , 4 1}$ & $\mathbf{0 , 8 2}$ & $\mathbf{1 , 1 1}$ & $\mathbf{1 , 6 8}$ & $\mathbf{2 , 0 7}$ & $\mathbf{4 , 8 2}$ \\
\hline Measured flow rate & $\mathrm{I} / \mathrm{h}$ & 90,4 & 44,9 & 32,9 & 21,8 & 17,7 & 7,6 \\
\hline Peak retention time, $\mathrm{t}_{\mathrm{r}}$ & minutes & 49 & 32 & 68 & 38 & 38 & 40 \\
\hline Peak width at half-height, $\mathrm{W}_{\mathrm{h}}$ & minutes & 32 & 16 & 47 & 36 & 30 & 41 \\
\hline Number of theoretical plates, Ntp & & 13 & 22 & 12 & 6 & 9 & 5 \\
\hline Height equivalent of a theoretical plate, HETP & $\mathrm{mm}$ & 35 & 21 & 40 & 77 & 54 & 87 \\
\hline Mobile phase velocity & $\mathrm{mm} / \mathrm{min}$ & 17 & 8 & 6 & 4 & 3 & 1 \\
\hline
\end{tabular}

Figure 15 Data used to make the Van Deemter plot 
The recommendations that follow from the residence time study are:

- HRT for the AFBR configuration tested (packing volume, packing dimensions, column geometry, etc.): between 0,4 and 1,1 hours

- Mobile phase velocity: between 6 and $16 \mathrm{~mm}$ per minute

\section{Discussion and conclusions}

\section{Observed bioreactor performance and projected scale-up}

The important average influent and effluent characteristics and the values achieved during the pilot tests are presented in the tables below. Achieved values are those that were maintained stable for several days. Expected values are predicted based on the results of the pilot tests and subjective judgement.

Table 9 Expected influent and effluent characteristics

\begin{tabular}{|l|c|c|c|c|c|}
\hline \multicolumn{1}{|c|}{ Influent } & Unit & Overall average & RSD [\%] & Achieved & Expected \\
\hline Total COD & $\mathrm{mg} / \mathrm{l}$ & 685 & & & 685 \\
\hline Total solids & $\mathrm{mg} / \mathrm{l}$ & 646 & 6 & & 650 \\
\hline Volatile solids & $\% \mathrm{TS}$ & 37 & 22 & & 37 \\
\hline Higher heating value & $\mathrm{kWh} / \mathrm{m}^{3}$ & 1.04 & 36 & & 1 \\
\hline \multicolumn{1}{|c|}{ Effluent } & & & & & \\
\hline Total COD & $\mathrm{mg} / \mathrm{l}$ & 347 & 31 & 56 & 150 \\
\hline Total solids & $\mathrm{mg} / \mathrm{l}$ & 504 & 20 & 400 & 500 \\
\hline Volatile solids & $\% \mathrm{TS}$ & 29 & 23 & 25 & 25 \\
\hline Higher heating value & $\mathrm{kWh} / \mathrm{m}^{3}$ & 0.29 & 49 & 0.25 & 0.25 \\
\hline
\end{tabular}

Table 10 Summary of AFBR performance

\begin{tabular}{|l|c|c|c|c|c|}
\hline AFBR performance & Units & Overall average & RSD [\%] & Achieved & Expected \\
\hline Hydraulic retention time & hours & 4.7 & 122 & 2.8 & 3 \\
\hline Temperature & ${ }^{\circ} \mathrm{C}$ & 23 & 30 & 16 & $>16$ \\
\hline Methane production & $\mathrm{vv} /$ day & 0.44 & 42.5 & 0.6 & 0.7 \\
\hline Biogas $\mathrm{CH}_{4}$ content & $\%$ volume & 65 & 15 & 70 & 65 \\
\hline Total solids loading rate & $\mathrm{Kg} \mathrm{TS} / \mathrm{m}^{3} /$ day & 4.6 & 49 & 7 & 7 \\
\hline Organic loading rate & $\mathrm{kg} \mathrm{VS} / \mathrm{m}^{3} /$ day & 1.7 & 61 & 4 & 10 \\
\hline COD reduction & $\%$ & 58 & 28 & & 75 \\
\hline HHV reduction & $\%$ & 71 & 14 & 85 & 80 \\
\hline
\end{tabular}

The average inlet COD $(429 \mathrm{mg} / \mathrm{l}) \times$ average flow rate $(268 \mathrm{l} /$ day)/ filter bed working volume (56 litres) $=2,1 \mathrm{~kg} \mathrm{COD} / \mathrm{m}^{3} /$ day.

Table 11 AFBR description of industrial scale AFBR

\begin{tabular}{|l|l|c|c|}
\hline \multicolumn{2}{|c|}{ Anaerobic filter bioreactor description } & Achieved & Expected \\
\hline Biofilm specific area & $\mathrm{m}^{2} / \mathrm{m}^{3}$ bulk volume & 360 & 360 \\
\hline Biofilm thickness+ & $\mu \mathrm{m}$ & $100^{*}$ & 300 \\
\hline Biofilm specific mass & $\mathrm{mg}$ VSS/I reactor & $36^{\prime} 507$ & $164^{\prime} 280$ \\
\hline Effective volume* & $\%$ of actual volume & $67^{*}$ & 99 \\
\hline Bed volume requirement & $\mathrm{m}^{3} / \mathrm{MLD}$ influent & 196 & 29 \\
\hline Biofilm support material & & Torrefied chips & Torrefied chips or plastic \\
\hline
\end{tabular}

${ }^{+}$assumed mean thickness based on visual observation that the chip surface was not yet completely covered.

* Based on tracer studies that show that for the average HRT of 4,7 hours observed during the study, the peak effluent salt tracer concentration occurs at $67 \%$ of the theoretical HRT.

The main needs for further development are: 
- Hydrodynamic models and detailed design of the AFBR bioreactor

- Design, construction and testing of features that will be required at the industrial scale (e.g. high-rate primary sedimentation basin, back-washing, bed materials, heating mode, effluent solid-liquid separation)

- Development of biochemical and kinetic model

- Large-scale (>4 $\mathrm{m}^{3}$ bioreactor) long duration (18 months) testing

- Design, construction and testing of a thermal energy collection, storage and distribution system

The AFBR project can be conducted as a standalone project or, preferably, as part of a project to develop a completely new wastewater treatment plant incorporating a new primary treatment process, nutrient removal, algae photo bioreactors, $\mathrm{CO}_{2}$ recycling, advanced biogas cleaning techniques and combined heat and power concepts, novel final effluent polishing processes, and water reuse.

\section{Biofilms and packing material}

The results of the three different methods used to assess the biofilms lead to the following main conclusions:

- A robust biofilm developed on the torrefied wood chip supports

- Torrefied wood is an acceptable biofilm support material

- A biofilm developed on the plastic supports

- Biofilm development is slow. It appears that at least 1 month is required for establishment of the biofilm and that one can expect the biofilm to continue to increase in surface coverage and biomass over time

- The biofilm tolerated cold conditions $\left(8^{\circ} \mathrm{C}\right)$. Maintenance of at least $16^{\circ} \mathrm{C}$ inside the biofilter bed appears to be a reasonable objective for future development

Further evidence of the existence and activity of a biofilm is given by the measured biochemical conversions. In particular, the short hydraulic retention time, the higher heating value reductions and the COD removals would not have been possible without active immobilized biomass.

The observation that the UAF elimination capacity increased during the study as the hydraulic retention time decreased and as the temperature decreased suggests that the mass of the biofilm was increasing during the study and had not reached a limit. Further increasing the mass of the biofilm might result in even better performance.

Due to the strict limits on effluent turbidity and the unknown effect of torrefied wood particles on conventional wastewater treatment processes, further work will be focussed on the use of synthetic biofilm support materials. Differences between the type of plastic material were observed in terms of biofilm coverage and in specific biofilm activity as determined by the ADH assay. The micropollutant adsorption capacity of torrefied chips should be investigated. Due to their low cost compared to plastic, torrefied chips might be appropriate biofilm support materials in lower income countries.

\section{Acknowledgements}

This research project was financially supported by the Swiss Innovation Agency Innosuisse and was part of the Swiss Competence Center for Energy Research SCCER BIOSWEET. A student intern made a major contribution to adapting the DHA activity assay and to sampling and analysis of the physicalchemical parameters. 